\title{
The Refined Image of the Oriental in Browning's Two Victorian Plays: A Psychoanalytic Reading
}

https://doi.org/10.33806/ijaes2000.22.1.4

\author{
Hanan Khaled Al-Jezawi \\ Al Balqa Applied University, Jordan
}

Received on 10.1.2021

Accepted on 15.6.2021

Published on 1.1.2022

\begin{abstract}
The purpose of this paper is to examine the way in which Robert Browning dissociates himself from the predominant Orientalist mode that viewed the Orient as a zone for exoticism. Despite his misconception of the Orient, there are bright aspects in his plays which can be described as a kind of reverence and respect. The study is a psychoanalytic reading of the oppressed Oriental who tries to assimilate, yet he fails. Consequently, psychological problems such as alienation that results from racial prejudice, a damaged self-esteem, and suicidal thoughts develop. At the same time, the study examines betrayal. In other words, the characters surrounding the central character allow Browning to construe the loyalty of the protagonist and the reversal involved in betrayal as stoically accepted. Luria: A Tragedy (1846) and The Return of the Druses (1843) are two Victorian plays to be explored in this study drawing on Frantz Fanon's psychoanalytic criticism.
\end{abstract}

Keywords: alienation, assimilation, betrayal, Druze, Moor, psychology

\section{Introduction}

Many Victorian writers draw on their travels to the Middle East providing a catalogue of misrepresentations of the Orient. They misrepresent the Orientals as they view them through the philosophical lens of the West. Consequently, it has been a misleading experience of judging the Orient. This has brought forth a sense of alienation amongst the Orientals and asserts the idea that they are distant geographically and culturally. The Orient has been romanticized, as Edward Said suggests, and the transmission of knowledge has been only through the textual medium. The way some of these writers, including Michael Bonine and Bernard Lewis, construct the Orient's image gives the impression that their understanding of its people and their religion is shallow to a great extent. However, in his book Browning Upon Arabia: A Moveable East, Hedi A. Jaouad points out that Robert Browning departs from the classic Romantic tradition in that he does not romanticize the East (2018: 216). Unlike European writers and poets, he does not see the Easterners naïve to deal with the harsh world as a justification to rule them.

Orientalism has been rooted in three phases of eighteenth century European and British culture. First, The Arabian Nights, which was translated into French is in 1704. As a collection of folk tales compiled in Arabic, the tales convey to Europe the image of the Orient as a place of mystery and danger. Second, some Romantic poets represent the Orient in their works such as Samuel Taylor 
Coleridge's Kubla Khan, Percy Bysshe Shelley's Alastor and others. Third, there is the autobiographical account of Thomas de Quincy entitled Confessions of an English Opium Eater in which he writes about addiction and its effect on his life, and he describes Egypt specifically.

In Culture and Imperialism, Said asserts the role of the narrative in the nineteenth and the twentieth centuries in building the modern Western Empire. He points out that "stories are at the heart of what explorers and novelists say about strange regions of the world; they also become the method colonized people use to assert their own identity and the existence of their own history" (1994: xii). He believes that modern imperialism is based on a systematically effective vision of reality. This vision is directed by European science, which classifies people as superior/advanced and inferior/backward.

On the other side, the encounter between Islam and Christianity was not born in the nineteenth century. From the sixteenth to the nineteenth centuries, the Muslims' presence in Britain has been conditioned by the political climate between Britain and the Islamic power that reigned in the global south (Spain, India, and Turkey). However, reading about the representations of Islam and Muslims in nineteenth-century British literature has been a misleading experience since many "religious thinkers also hearken back to what has been narrated about Islam and try to reconstruct the image and present a real picture of the religion and its followers in order to [erase] hatred in the West towards Muslims and Islam" (Awajan and Shetawi, 2021: 127-128).This image has produced an alienating effect that seems to convey the message that Islam and Muslims are distant geographical and cultural entities. In truth, the only available accounts of the Orient for the Victorian authors is passed on through the textual medium.

This misrepresentation of Muslims and Islam is widely discussed by Said in his book Covering Islam. He states that malicious generalizations about Islam have become the last acceptable form of denigration of foreign culture in the West; what is said about Muslim mind, or character, or religion, or culture as a whole cannot now be said in mainstream discussion about Africans, Jews, other Orientals, or Asians (2015: 1). Such generalizations are not used to describe other religious or cultural demographic group as Said states (1997: xvi).

In Victorian Images of Islam, Clinton Bennett brings to the foreground an important moment in the history of the encounter between Islam and Christianity during the nineteenth century through the contribution of the Christian mission to Western scholarship about Islam. Bennett's project is generated by his conviction that the Western "present-day attitude towards Islam was fundamentally shaped not by these contemporary events but by our awareness of nineteenth-century attitudes, especially of missionary writing" (2009: ix).

Similar to Said, the psychiatrist and political philosopher Frantz Fanon examines the binary opposition between the West and the "Other". InBlack Skin, White Masks, Fanon represents the image of the "Other" in the white man's mind. $\mathrm{He}$ argues that the process of "Othering" is done by means of race. Fanon believes that what defines the value of one's skin color is the imperial encounter of white and black that creates awareness of culture otherness (2008: xxxv). The 
awareness of the master-slave relationship between the person of color (any person who is not considered white) and whites sheds light on the definition of racial identity which eventually leads to alienation that includes the sense of rupture. Fanon is different from other theorists for associating psychology with different domains especially politics and colonialism. Although colonization is geographical, there is also colonization of the mind that makes a group of people believe in their inferiority. Fanon explains how people struggle to decolonize their minds and assert their individuality and avert assimilation.

In Black Skin, White Masks, Fanon confirms that racial identity is sociopolitical; therefore, he believes that it is a prerequisite to understand the political and social elements of racial identity. He uses the conception of alienation as a form to understand racial identity (2008: 13). This alienation is a cultural trauma that "occurs when members of a collectivity feel they have been subjected to a horrendous event that leaves indelible marks upon their group consciousness, marking their memories forever and changing their future identity" (Alexander and Eyerman 2004: 1). Fanon is known for his main concern for people of color; that is why he criticizes Freud and Jung for disregarding the excruciating experience of the person of color. This distressing experience or psychological trauma survives in the unconscious and results in numerous psychological and physical problems that lead traumatized people to alienation and in some cases to committing suicide. Traumatized people cannot be cured easily; " The old Greek implication of the word 'trauma' is transformed from an injury caused by a physical act of violence on an individual, which can be healed, to a symbolic wound to an individual's psyche" (Muhi 2020: 135). Muhi adds that psychological trauma is associated with the mind and identity, which is revived and cured as a physical wound (2020: 135).

Robert Browning, a Victorian poet and playwright, displays his interests in writing about the Orient through his works. By way of illustration, his proclivity for the Orient's culture is unequivocally observable in his dramatic monologues such as Emir Abd-el-Khedar, the Algerian leader who resisted the French colonial invasion of Algiers in 1833, in his poem "Through the Metijda to Abd-el- Kadr"or in "Muleykeh" and "Clive".

This study sheds light on the psychology of the Orient based on Fanon's concept of psycho-politics. He introduces "a layered theoretical approach to the problems of black identity in racist colonial contexts" (Hook, 2004: 116). In Black Skin, White Masks, he examines the ramifications of racism, and refers to psychological formations to highlight the identity trauma of blackness in the colonial context.

This Study shows how the oriental person is affected negatively as a result of betrayal, religious prejudice, and rejection. Although he tries to assimilate with the other culture, he fails. Consequently, psychological problems such as grief, shock, a damaged self-esteem, and suicide develop. This reading shows that Browning is different from his contemporaries in that he does not represent the Orientals and their religion in a negative way; instead, he is unprejudiced. In the 
two plays under discussion, the Druses are identified as Arabs and the character Luria is a Moor, respectively.

\section{Browning's Luria: A Tragedy}

In Luria: A Tragedy, the protagonist Luria is a noble Moor in the service of Florence, devoted to the Republic, but distrusted as an alien. Browning highlights the tension between, the main character, Luria's Eastern nature and the Western Florentine army leaders. He discusses the issue of race through examining the relation between thoughts and emotions, passion and reason, which reflects Luria's Eastern nature. Many critics find that Luria: A Tragedy is an adaptation of Shakespeare's Othello. In both works, the main characters Luria and Othello are Moors and they serve their masters. Both Moor characters are betrayed although they are loyal to their masters; they are suspected and unappreciated by the city inhabitants they serve, and both commit suicide at the end.

The term "Moors" refers to "The Arab Muslims and their descendants by the Portuguese in the $16^{\text {th }}$ century and the term referred to their religion and was no reflection on their origin" (Mohan, 1987: 9). On the other side, Moors were also considered as black people: "there were white people in Europe looking upon the black people in Africa as Moors and, therefore, were looking at them in deprecating racial and racist terms" (Wright 2002: 99). Also, "at every phase of America's development you find Moors (black people)" (Najee-ullah, 2014: 31). Therefore, "Moors" can be related to Muslims or people of dark skin.

Browning interprets Luria's psychology by showing how his identity is constructed and developed throughout the play. The colonized person's identity can be formed either in resistance or in assimilation as Fanon believes. Fanon outlines three phases through which the native intellectual moves; this begins with deficient assimilation, then reconstruction of identity and the last one is resistance. The first step that Luria takes is assimilation. In Introduction to the Science of Sociology, Robert Park and E.W Burgess define assimilation as "a process of interpenetration and fusion in which persons and groups acquire the memories, sentiments, and attitudes of other persons or groups, and by sharing their experience and history, are incorporated with them in a common cultural life" (qtd. in Cutler, 2015: 3). Fanon rejects the idea of assimilation; he explains: "The black man wants to be like the white man. For the black man there is only one destiny. Long ago the black man admitted the unarguable superiority of the white man, and all his efforts are aimed at achieving a white existence" (2008: 178). Fanon's rejection explains two things: the first one is that the white man tells the man of color "be like me"; second, the white man believes that the other cannot be as good as him even if he tries to be a replica of him.

Luria, as a loyal Moor, is responsible for Florence's service and believes that he can bring the East and the West together. Thereby, he tries to assimilate to the European culture. In the first act, Luria is persuaded that he possesses the traits of a savage and feels the thrill as a barbaric: "Not one of you, and so escape the thrill/Of coming into you/ and changing thus/ Feeling a soul grow on me that restricts/ The boundless unrest of the savage heart!"/Horror, and silence, and a 
pause awhile" (1.154-158). The binary opposition is represented through Luria's nature as a savage and the conflict which emerges when he starts to follow his instincts: "creature of instinct." Moosavinia and Niazi explain that the savage is considered as "demonic or exotic". They explain that for the demonic, "the savage is evil as well as inferior", yet for the exotic, "the savage is perceived as possessing a primitive beauty or nobility born of a closeness to nature"(2011: 105). In the play, Browning refers to the savages as noble, which symbolizes humanity's innate goodness. Jean Jacques Rousseau depicts the noble savage as an infant or a child; his nature is good, but he is governed by self-love which has not turned to a sense of one's own worth (qtd in Maurice 1991: 176). Browning does not view savageness as something bad or evil; however, their simplicity leads them to follow their instincts, which are signs to the good life since they are not distorted by the regulations of civilization as Rousseau believes.

Fanon argues that the man of color believes that the white mask serves as a liberating tool and gives him the opportunity to move to a condition of individual presence instead of the condition of absence. This white mask appears when he hides his real identity and assimilates to the white culture(ix). Luria insists on assimilation since he hopes that this could affect his life positively. He informs Tuburzion, a commander of the Pisana, about his faith in Florence and declares that time of the savage instinct is over: "Such faith stays when mere wild belief would go/ Yes - when the desert creature's heart, at fault/Amid the scattering tempest's pillared sands" (2. 167-169). Luria criticizes the attributes of creatures of the desert that he belongs to, and believes they are just flaws. He reinforces this in the same act when he confesses to Tuburzion: "My simple Moorish instinct bids me sink/The obligation you relieve me from, still deeper!" (2.380). He tries to assimilate; yet, he finds it hard to negate his origins especially when he discovers that he is betrayed by them.

One of the main issues that Browning highlights and surmises to psychological problems is deceit and betrayal. Although Luria is leading Florence to victory, he is suspected by Braccio to be a traitor; Braccio fears that the Moor would keep his position until the end of the war. Although Luria moves to the West, assimilates to them, and becomes the most loyal to them, he is betrayed. On the eve of the battle, Luria is warned and he is given a letter that proves the treachery of the Florentines. Luria takes the letter but does not break the seal. He tries to deny the betrayal of the Florentines: "Yes: I trust Florence-Pisa is deceived" (2.319). Luria understands that they will fail him but he remains in a state of denial: "Give me one last happy moment, friends!/You need me now, and all the gratitude this letter can contain will never balance the after-feeling that you need's at the end" (2.168-171). He asks Braccio and Puccio if he could open it, then he tears up the letter and rushes to the battle.

Luria is aware of the treachery; yet, when Puccio advises him to turn his troop against Florence, the latter refuses to take revenge and utters: "I ruin Florence, teach her friends mistrust, / confirm her enemies in harsh belief" (2. 195-196). He remains loyal and will always be faithful to the end because he does not want the Westerners to describe him as betrayer or to attribute betrayal to his 
origins. Husain warns him and explains that they are exploiting him: "I doubt and fear. There stands a wall/ 'Twixt our expansive and explosive race/And those absorbing, concentrating men! /They use thee! (2. 159-163). Luria discovers his blindness late. When he reveals Florence's betrayal, he mocks himself saying: "The Moor's dull mute inapprehensive mood,/Was saving you; I bore and kept my course:/ Now real wrong fronts me-see if I succumb" (3. 184-186). He derides his loyalty, which has been confronted by betrayal; however, he clings resolutely to his noble features. This explains how the loyalty of the protagonist and the reversal involved in betrayal are stoically accepted.

Browning, through his representation of Luria, is adamant about showing Luria's loyalty even when he is betrayed. Browning praises Luria's interiority that does not change. For, example, Puccio, the commander who is replaced by Luria, feels that Luria is wronged by the others; he confesses to "[Luria's] better nature, fresh-inspired, / Mounted above me to its proper place!" (4. 187-188). Not only does Browning explain how the westerners view Luria as a Moor but he also explores Luria's mind to show how he is different from the stereotype that the West propagates.

Tiburzio, Luria's honest and noble rival, criticizes Florence's treachery; nonetheless, Luria does not react immediately to what he discovers, and chooses to be rational. Unlike Shakespeare's Othello, who is emotionally aroused when he has been informed of his wife's betrayal and makes an impetuous decision of murdering her. Luria says: " And act on what I read? What act were fit?/If the firm-fixed foundation of my faith/ In Florence, who to me stands for Mankind /If that break up and, disemprisoning/From the abyss....Ah friend, it cannot be/ (2. 165-168).

Luria shows loyalty to Florence when he visits Puccio after he swallows the fatal poison to give the new commander advice that will assure the ultimate control of Florence against the enemies although he is sure they have betrayed him. Puccio is overwhelmed with grace that Luria has chosen to help him, which leads to a revelation about Luria's nobility. Puccio cries:

I am yours now, - a tool your right-hand wields./ God's love, that I should live, the man I am,/ On orders, warrants, patents and the like,/As if there were no glowing eye i' the world/To glance straight inspiration to my brain,/ No glorious heart to give mine twice the beats!/ For, see-my doubt, where is it? - fear? 't is flown! ( 5.99).

Puccio realizes that until the time when he knew Luria, he has lived on "orders, warrants, patents," or within the domain of logic, whereas Luria's insight "glowing eye" and his spiritual vision has brought knowledge of soul to Puccio's brain, that for Browning is the adapted faculty.

Betrayal and racial prejudice lead to a psychological problem, namely alienation. Braccio, the Commissary of the Republic of Florence, describes Luria as an "alien", "inevitable foe" and "a Moor", "no past with us, no future" (1. 147). This description depresses Luria, especially after all the efforts he has made for them and reinforces his feeling of alienation. Fanon focuses on alienation and 
psychological marginalization. He points out that "[b]oth the black man, slave to his inferiority and the white man, slave to his superiority, behave along neurotic lines. As a consequence, we have been led to consider their alienation with reference to psychoanalytic descriptions" (2008: 42).

As a Moor, Luria is considered an alien by the Europeans; he also asserts his alienation when he tells Domizia and Braccio that he is "Not one of [them]", and later, he calls himself "an alien force": "yes, an alien force like mine/Is only called to play its part outside/Their different nature; where its sole use seems/To fight with and keep off an adverse force/As alien" (2. 160-164). He has little chance to be accepted or appreciated by the Florentine society no matter how hard he tries because he does not carry the pure blood possessed by the Florentines. Fanon believes that "[i]n the man of color there is a constant effort to run away from his own individuality, to annihilate his own presence. Whenever a man of color protests, there is alienation. Whenever a man of color rebukes, there is alienation" (2008: 60). This is the case of Luria at the end; he turns to the whole racial trauma resulting from experiencing racial violence, and causing the feeling of humiliation and low self-esteem.

In The Soul of Black Folk, the American sociologist and civil rights activist writer, W.E.B Du Bois elucidates how black people who are considered "inferior" view and judge themselves through the eyes of the other: "It is a peculiar sensation, this double-consciousness, this sense of always looking at one's self through the eyes of others, of measuring one's soul by the tape of a world that looks on in amused contempt and pity" (2015: 3). Du Bois calls this "double consciousness" or "Twonness' since the dark individual regards himself through a white perspective while maintaining his self-definition. Therefore, the person feels that he lives with two thoughts and two different souls. Fanon shares with Du Bois the idea of double consciousness and the crisis of recognizing and constructing the self; he comments:

In the white world, the [person] of color encounters difficulties in elaborating his bodily schema ... by the other, the white man who had woven me out of a thousand details, anecdotes and stories ...

As a result, the body schema...collapsed, giving way to an epidermal racial schema (2008: 110).

Fanon associates these interests with the phenomenology of embodiment and everyday experience.

What is worth mentioning is that Browning endeavors to demonstrate how the West is trying to shape the identity of the "Others" as process of exploitations". Husain, a fellow Moor and Luria's friend, attempts to open Luria's eyes to the truth that he is just playing a role in a play and they are molding his identity the way they want. He tells Luria: "Then, hold thy course, my King!/The years return. Let thy heart have its way!/Ah, they would play with thee as with all else?/Turn thee to use, and fashion thee anew" (4. 189-192). Husain realizes that there stands a wall of racism that makes them exploit the Moor. Later, Luria shares with Husain the same belief: "And I feel it, Husain; yes,/And care notyes, an alien force like mine/ Is only called to play its part outside/Their different 
nature; where its sole use seems/ As alien,- -which repelled, mine too withdraws" (2. 160-165). He confesses that he feels like an alien among them.

Through developing his character as a Moor or a dark person, Luria starts to identify himself as he discovers in act III that he is strong as a savage. He tells Florence: "Is it to be?-You will know all the strength/Of the savage- to your neck the proof must go? /You will prove the brute nature? Ah, I see!/The savage plainly is impassible" (3.183-186). He ends up, in act IV, confessing his blindness saying: "Ah, we Moors get blind Out of our proper world where we can see!"(4.196). Previously, he was blind to the fact that he will never be one of them, then he realizes how his assimilation to the Florentines is a mistake.

In The Wretched of the Earth, Fanon refers to the "new man", and in Black Skin, White Mask, he depicts him and says that this man finds himself " in a world in which things do evil"; a world in which he is called into battle (2008: 228). The new man is associated with other postcolonial concerns, such as the replacement of the depressing racist society with a new one. Luria finally admits that he was born a Moor: "I, born a Moor, lived half a Florentine;/But, punished properly, can die a Moor/ Beside, there is what makes me understand/ your nature... I have seen it. (5.205-208). He reveals his failure after having lived "half Florentine". This makes him drink the potion and kill himself; it is better to die than to be a traitor. Such a closure discloses Browning's conviction that psychological stress led to Luria's suicide. Feeling depressed by being deceived leads to alienation and this leads him to self-destruction. On the other hand, Fanon explains in The Wretched of the Earth, that the inferior race, proudly prefers death when fighting for freedom. The real tragedy for him is not death; it is the fact that he has never been appreciated. The development of Luria's character throughout the five acts helps him discover his true identity as a Moor; yet, it is only later that he becomes proud of his origin.

Furthermore, Browning is objective toward the oriental religion, which explains how he is different from the predominant Orientalist mode of that time. Historically, the term Moor refers very often to Muslims. In Xenophobia and Islamophobia in Europe, Raymond Taras explains that Maurophobia (the fear of Moors) is "a mixture of Muslim groups [such as] African Arabs, Iberian converts to Islam" (2012: 15). Browning represents religion in the East in a positive way throughout the character of the Moor, Luria, who reveals:

My own East!

How nearer God we were! He glows above

We feel Him, nor by painful reason know!

(5. 206-208)

Browning displays the idea that the Easterners can feel God and approach the divine by intuition, not the intellect. They feel close to him spiritually and feel him over their souls. It seems like Browning is trying to answer the question of the way God treats these souls. God works upon them in the spirit of thought and passion which he puts into them, which Luria considers "the East's gift" (5.206). 


\section{Browning's The Return of the Druses}

The Druze are a Middle Eastern ethnic sect, and most of them are descendants of Arab tribes that immigrated to Syria (Firro 1992: 19). In Muslims in Australia, Nahid Kabir points out that the Druzes are normally "followers of the Islamic Faith", (2013: 1) but many of them have relinquished the Islamic doctrine; they started calling themselves believers in the unity of God "unitarians" (alMuwahhidun). Moreover, the Druze have a belief in a manifested God. The last was Hakem-Biamr-Allah, the sixth Fatimid caliph, who claimed divinity.

In his article "Class or Internal Partisan conflict in the Druze Sect", Salman Falah observes that the split of the Druze throughout history has made them lose their power, especially in Lebanon since the Druze live mostly in Lebanon, Syria, and Palestine. This split dominates the Druze denomination in Lebanon; however, this does not exist in Syria or other places. This split is represented in Browning's play; he employs two different characters from two different types, namely, ignorant and wise.

The play is structured around the familiar Orientalist oppositions of the superior West and the inferior East. However, Browning considers Druzes's victims of racial discrimination. The Druzes ran away from Ottoman tyranny to the Island under the rule of the knights of Rhodes, yet they find themselves hostages not hosts. There is a negative influence of Europeans on the protagonist Djabal, who claims divinity and explains that this is because some Druze follow their senses and emotions; therefore, he has to claim divinity to protect his task and to free his people from tyranny and return to Lebanon. He has falsely announced to be the reincarnation of the Hakeem. Djabal feels guilty about his disguise, but he tries to appease his feelings by thinking of his adventure to help the Druze. After traveling the world to seek allies for his tribe, he asks: "could I call / My mission aught but Hakeem's? Promised Hakeem / More than performs the Djabal-you absolve?" (2. 81-83). Khalil, Djabal's close friend who represents the pious Druze, explains to Karshook, a fellow Druze, that without Djabal's disguise, the Druze's tribe would remain subject to the Christian Knights of Rhodes who have kept them under the subjugation of the authority of a corrupt Prefect since they fled from Lebanon and sought their help in escaping the Ottoman Empire.

In the play the characters are not aware of their double consciousness; however, with the progression of the events, they become aware and start to desire their identity. Fanon describes the inferior race in Black Skin, White Masks:

[He] has been given two frames reference within which he has to place himself customs and the sources on which they are based we wiped out because they were in conflict with a civilization that he did not know and that imposed itself on him. (110)

Throughout the process of identifying the self, the inferior race starts with assimilation. Djabal attempts to bring the East and West together. He assimilates to the European culture and endures the doom of the inferior race since he is represented as an alienated colonial subject. Compared with the Westerners, the 
Druze are described as children of the desert and savage. Khalil describes Lebanon as "somber groves".

The idea of assimilation is clear in this play; Djabal, tries to assimilate with the Europeans although he knows that his race is older than theirs: "the Druses are older than the oldest, princelier than Europe's princeliest race, our tribe" (4. 117). His "Syrian blood" indicates the intuitive perception. Later, he declares that he has attempted to assimilate and feels torn between his "Arab instinct" and his "frank brain" that punishes his Arab heart. Hedi Jaouad explains that Djabal has two identities with "Frankish and Arabic sides" (2018:144), and his soul is divided between "Arab instinct" and "Frank schemer". Browning wants to show that the Frankish domination or the exploitation by the Frankish oppressor is unacceptable. Moreover, there is a racial prejudice that is inherited. For example, Loys, the only Christian the Druze trust, remained prisoner to the Frankish pride and scorn. Although Djabal is his best friend, he does not judge him as equal. Jaouad adds that Djabal replicates the acts of the other party by mimicking them (2018: 135). Therefore, Browning depicts Djabal as a clever person who uses the European "Frank policy" to help him reach his target, and to continue with his plan to save his people since Frank pride is "hegemonic and domineering", which contrasts with Arab pride ( Jaouad 2018: 111). On the other hand, he depends on his Arab instinct or the savage instincts "to act his part with ease" as Herford explains (qtd. In Jaouad 2018: 71).

The binary opposition between the West and the East is manifested in Djabal's " policy" and "Frank brain". Although the stereotype is that Arabs are more likely to follow their instincts and hearts rather than their reason, Browning exhibits how the Easterners can use reason, and the Arab instinct, on the other hand, is not bad or corrupted. Similar to Luria who has reacted rationally when he is betrayed instead of avenging, Djabal does the same thing when he finds out Anael's perfidy. Djabal declares to Anael:

I with my Arab instinct, thwarted everywhere

By my Frank policy, - and with, in turn,

My Frank brain, thwarted by my Arab heart-

As a Frank schemer or an Arab mystic (5. 132-135)

Themes of betrayal and loyalty are at the core of identity-centered works. Betrayal is represented in the play and it affects the characters and their identities. For instance, the European De Drux who discarded his prejudice in dealing with Druzes and appeared to be different from the rest of his race, he later follows their same attitude. When his chance comes to rule the island, he wants Anael, Djabal's lover, to become his property to conduct a war against Druzes. Such betrayal affects Djabal in a negative way. He describes his deception to himself: "Has Europe then so poorly tames/ The Syrian blood out thee?/ Thou, presume/ To work in this foul earth by means not foul? (4.113-116).

Similar to Luria, Djabal does not meet betrayal with betrayal although it is the most painful experience. This psychological problem makes him believe that by committing suicide he frees himself from oppression and betrayal. He prefers 
to kill himself rather than take revenge. As a result of the unresolved anguish, he suffers anxiety that drives him to brutal behaviors toward himself.

Browning is unbiased toward the oriental religion. Seemingly, Browning intends to show that not all Arabs believe in superstitions. Djabal explains to Loys that he does not believe in superstition and that he wants to go in line with the Druze to help them since some of them believe in this superstition: "Our Druses are enough/ To crush this handful: the venetians land/ Even now in our behalf" (4.117-119).

Browning highlights the Druez's superstitions about viewing the miracle of the reincarnated divine; however, he tends to explain how Djabal corrects the idea by saying that it is not necessary to see the incarnated Hakeem or to know the divine since a true miracle is love and it is not more than a superstition. Djabal's last speech, when he calls upon the Druzes to start their home journey, is significant since he asserts that love is the way to the divine. Djabal explains to his lover Aniel earlier in the play: "I saw my tribe: I said, 'Without / A miracle this cannot be' - I said / 'Be there a miracle!' - for I saw you" (4.110-113). Browning asserts that through human love one can intuit God; Djabal conveys: "What matters was my purity of soul/ Heaven would accept me for its instrument, I hoped: I said heaven had accepted me" (4. 110-111). Although Djabal has proclaimed divinity and becomes the manifested God "Hakeem", he, afterwards, confesses his lie and explains that it is a "superstition". Therefore, by representing the issue of religion in the East in an objective way, Browning can be considered unbiased; he does not misrepresent the Orientals or their religion; they are represented as people who are forgiving. Islam is introduced as a religion that grants its believers with internal love and peace, and provides psychological balance.

\section{Conclusion}

Browning admires the Arabic culture in different ways on the basis of the references present in his works. This enhances the researcher's belief that Browning has a different perspective regarding Arabs and Muslims. Browning, in his two plays, does not intend to reinforce the stereotype of the Orient; instead, he criticizes the way the West interacts with the East. By examining themes of assimilation, alienation and betrayal that affect the psychology of the inferior race, Browning views the oriental from a different point of view.

Fanon focuses on the "inferiority complex", which is attained from the juxtaposition of the black and white races. He explains how many psychological problems are caused by racism. When black people view themselves from the perspective of white people, they develop an inferiority complex, which in turn has psychotic consequences. The person who develops an inferiority complex is searching for an identity; this is why he should be conscious of who he is.

Browning examines the psychology of the oppressed oriental throughout following the protagonists' attitudes. In the works under examination, Luria and Djabal seek to bring the East and West together but in vain; they try to assimilate but finally they believe that they bring the two aspects together. This assimilation 
becomes as a tool to cope with the trauma. Moreover, Browning makes a question of loyalty that does not switch to betrayal in the protagonist's interiority. When the protagonists in the play discover that they are betrayed, they do not complain. This does not mean that they are not affected psychologically by betrayal; the appalling experience is repressed in the unconscious, and causes psychological problems that lead to suicide. Being betrayed by the superior race leads Luria and Djabal to a state of depression, and the result is committing suicide. This suicide is considered as freedom from oppression and betrayal.

Hanan K. Al-Jezawi

English Language and Literature Department

Al Balqa Applied University, Jordan

ORCID Number: 0000-0003-4004-1467

Email: Jeezawi@bau.edu.jo 


\section{References:}

Alexander, Jeffrey, and Ron Eyerman. (2004). Cultural trauma and Collective identity. California: University of California Press.

Awajan, Nusaybah, , Mahmoud Al-Shetawi. (2021). 'Empowering Muslims in Leila Aboulela's Minaret and Mohja Kahf's The Girl in the Tangerine Scarf'. International Journal of Arabic-English Studies, 21(1): 127-144.

Bennett, Clinton. (2009). Victorian images of Islam. New Jersey: Gorgias Press.

Browning, Robert. (1849). A blot in the 'scutcheon. The return of the Druses. Luria. A soul's tragedy. Dramatic romances and lyrics. London: Chapman \&Hall.

Cranston, Maurice. (1991). The noble savage: Jean-Jacques Rousseau, 17541762. Chicago: University of Chicago Press.

Cutler, John. (2015). Ends of assimilation: The formation of Chicano Literature. Oxford: Oxford University Press.

Du Bois. W. E. B. (2015). The souls of black folk. New Haven: Yale University Press.

Falah, Salma. (2008). 'Class or internal partisan conflict in the druze sect'. AlAMAMAH. $2008 . \quad$ Retrieved from http://www.alamam/index.php?option=com.content\&task= view\&id=494

Fanon, Frantz. (2008). Black skin, white masks. New York: Grove/Atlantic.

---. (2004). The wretched of the earth. Richard Philcox (trans.). New York: New York Grove Press.

Firro, Kais. (1992). A history of the druzes. Netherlands: Brill.

Hook, Derek. (2004). Critical psychology. Cape Town: Juta and Company LTD

Jaouad, Hedi. (2018). Browning upon Arabia: A moveable east. New York: Sprenger.

Kabir, Nahid. (2013). Muslims in Australia. London: Routledge.

Mohan, Vasundhara. (1987). Identity crisis of Sri Lankan Muslims. Delhi: Mittal Publications.

Moosa, S.R., NozarNiazi, and Ahmad Ghaforian. (2011). 'Edward Said's orientalism and the study of the self and the other in Orwell's Burmese days'. Studies in Literature and Language, 2 (1):103-113.

Muhi, Maysoon. (2020). 'The Deeper wounds: Living in the trauma zone in

Jawad Al-Assadi's Baghdadi Bath and Mithal Ghazi's A Feminine Solo'. International Journal of Arabic-English Studies, 20 (2): 133-148.

Najee-Ullah, Tawheeda, and Victor Taylor. (2014). Moors in America: A compilation. Chicago: Califa Media Publishing.

Said, Edward. (1994). Culture and imperialism. New York: Vantage Books.

---. (2014).Orientalism. New York: Knopf Doubleday Publishing Group.

---. (2015). Covering Islam: How the media and the experts determine how we see the rest of the world. New York: Knopf Doubleday Publishing Group. 
Taras, Raymond. (2012). Xenophobia and Islamophobia in Europe. Edinburgh: Edinburgh University Press.

Wright, William. (2002). Black history and black identity: A call for a new historiography. California: Greenwood Publishing Group. 